\title{
América Latina por trás das Fotos: a Vivência com Povos e Comunidades Latino-americanas como Instrumento de Formação Social e Profissional ${ }^{1}$
}

\author{
América Latina detrás de las Fotos: la Vivencia con Pueblos y \\ Comunidades Latinoamericanas como Instrumento de Formación Social y \\ Profesional
}

\section{Latin America behind the Photos: Living with Latin American Peoples and Communities as an Instrument of Social and Professional Formation}

\author{
Danilo de Santana Cardoso²
}

\begin{abstract}
Resumo
Este artigo traz reflexões sobre um conjunto de vivências acadêmicas que percorreram povos e comunidades no Brasil e outros países latino-americanos. A partir de uma experiência pessoal, registros fotográficos e diálogos com os nativos, tenta-se romper com a polarização existente entre saber científico e o popular, através de uma interpretação friccional destes. O compromisso social e profissional entram em discussão ao se analisar o papel do pesquisador durante esse processo formativo, destaca-se, também, a aproximação dos povos e comunidades nativas com a possibilidade de disseminação de suas práticas, saberes e a chance de (re)interpretá-los, rompendo com as antigas barreiras que limitavam essas e outras discussões ao espaço acadêmico. Consequentemente, a viagem, a presença e os diálogos garantiram a ampliação da visão da América Latina na América Latina.
\end{abstract}

Palavras-Chave: Vivência; Povos e Comunidades Latino-americanos; Formação Social e Profissional.

\section{Resumen}

Este artículo trae reflexiones sobre un conjunto de vivencias académicas que recorrieron pueblos y comunidades en Brasil y otros países latinoamericanos. A partir de una experiencia personal, registros fotográficos y diálogos con los nativos, se intenta romper con la polarización existente entre saber científico y lo popular, a través de una interpretación friccional de éstos. El compromiso social y profesional entran en discusión al analizar el papel del investigador durante ese proceso formativo, se destaca también la aproximación de los pueblos y comunidades nativas con la posibilidad de diseminación de sus prácticas, saberes y la oportunidad de (re) interpretarlos, rompiendo con las antiguas barreras que limitaban esas y otras discusiones al espacio académico. En consecuencia, el viaje, la presencia y los diálogos garantizaron la ampliación de la visión de América Latina en América Latina.

Palabras claves: Vivencia; Pueblos y Comunidades Latinoamericanos; Formación Social y Profesional.

Abstract

This article reflects on a set of academic experiences that have touched peoples and communities in Brazil and other Latin American countries. From a personal experience, photographic records and dialogues with the

\footnotetext{
1 Artigo apresentado no II Seminário Latino-Americano de Estudos em Cultura - SEMLACult em Foz do Iguaçu/PR, Brasil, 2018.

2 Bacharel em Ciências Sociais; Universidade do Estado da Bahia - UNEB; Salvador, Bahia, Brasil; danilocardosoemail@gamil.com.
} 
natives, one tries to break with the polarization between scientific and popular knowledge, through a frictional interpretation of these. The social and professional commitment are under discussion when analyzing the researcher's role during this formative process, it is also important to point out the approximation of native peoples and communities with the possibility of dissemination of their practices, knowledge and the chance of (re) to interpret them, breaking with the old barriers that limited these and other discussions to the academic space. Consequently, the travel, presence and dialogues ensured the expansion of Latin America's vision in Latin America.

Keywords: Experience; Latin American Peoples and Communities; Social and Professional Formation.

\section{Sinônimo de uma introdução: um começo}

Esse artigo surgiu da necessidade de um respiro profundo diante da minha intensa vida acadêmica quando resolvi acionar o elemento "retornança" para reflexionar sobre um conjunto de vivências com povos e comunidades tradicionais no Brasil e para além dele. Essas experiências afetaram a minha formação social e profissional, mas como afirmou Julian Barbuor, físico britânico, em sua obra The end of time: the next revolution in our understanding of the universe, se tentarmos agarrar o tempo com as nossas próprias mãos, ele estará sempre deslizando entre os nossos dedos (BARBUOR, 1999), então, para evitar esse acontecimento mantive a produção contínua de um diário de campo em que abusei de descrições densas para poder retornar em um momento oportuno ao passado e a essas realidades reminiscentes.

Ao acionar esses elementos em conjunto, passo a acessar questões implícitas que estão relacionadas ao comportamento e a vida social daqueles indivíduos tendo como suporte um conceito de cultura específico, que costumo utilizar para poder organizar o meu entendimento. Ele parte de uma leitura semiótica, no qual considera que o homem está amarrado em um emaranhado de teias de significados que ele mesmo teceu (GEERTZ, 2008). Dessa forma, esse conceito, que manuseio, permite a construção de uma interpretação e transformação da cultura em texto distanciando-se da busca excessiva por leis gerais, mas tentando encontrar os significados e códigos por trás daqueles momentos dialógicos, compartilhamentos, trocas de saberes e mostragem da cultura local.

Nesta análise fazendo uso da minha imaginação antropológica, vejo que os processos a serem apresentados podem ser vistos como unidade que ao mesmo tempo são dissociáveis devido aos múltiplos aspectos que os transformaram em um texto poeticamente comunicado aqui e agora através da minha sonoridade semântica, buscando ritmos, visualizando fotos e situações que produziram sentido para mim e para eles. Continuando a inscrever-me em meio aqueles outros sujeitos, sigo inscrevendo-os, e eles a mim. 


\section{Movimento dos Trabalhadores Sem Terra - MST e a resistência camponesa: o princípio}

Neste fragmento apresento uma breve leitura sobre MST in loco tendo como norte a minha vivência em um acampamento do MST localizado nas proximidades do município de São Sebastião do Passé, na Bahia. A luta pela terra aparece enquanto questão primaz estando presente nas narrativas desde a ação de entrada na fazenda a resistência contra ações de desocupação. Esse processo é uma lição admirável. O diálogo intenso com os campesinos ajudam a entender mais sobre as formas de atuação, organização, sobrevivência de um dos maiores movimentos sociais brasileiro.

Durante essa leitura será impossível dissociar a questão da ocupação da terra com a intensificação da concentração fundiária em nosso país. Mas como tudo isso começou? Como esse movimento surgiu? Em resumo, com fim do cativeiro humano em nosso país os poucos que sobreviveram ao genocìdio e o massacre da escravização passam a travar a luta pela terra. Alguns povos indígenas partem para o centro-oeste e outros, tal como os escravos libertos, migram para localidades mais adjacentes ao litoral, mas encontram grandes faixas de terras cercadas. Esse processo de migração extensiva e peregrinação acaba dando origem a várias formas de resistência como o Contestado, a Revolta de Canudos e outros movimentos messiânicos. Lutar contra o cerco era enfrentar a ira dos coronéis os "senhores absolutos" que se valiam da força policial para reprimir esse contingente de desamparados. Houve a eclosão de pelejas em quase todo território nacional causando a união de alguns grupos camponeses para enfrentamento da política imposta, agora, pelo regime militar que impulsionava a "colonização" de terras longínquas do território nacional, mas com o tempo viu-se que esse modelo era catastrófico para centenas de famílias pois os lugares ofertados não tinham condições mínimas para sobrevivência destes.

Nesse período, houve a intensificação da migração de camponeses para os centros urbanos em busca de melhores condições de vida. Um grande número continuou desempregado ou foram subempregados. A economia brasileira começou a dar sinais de recessão, sobretudo, no início em 1980. Alguns tentam resistir passando a ocupar áreas irregulares nos centros urbanos e outros passam a se mobilizar para retornar à terra natal. Em 1984, a Comissão Pastoral da Terras, movimentos sociais campesinos e sindicatos de 
trabalhadores rurais gestaram um processo de convergência de forças política dando origem ao $1^{\circ}$ Encontro Nacional de Trabalhadores Rurais Sem Terra, que fundou o MST.

O MST surge em meio a uma nova conjuntura agrária do país marcada pelo poder dos latifundiários, que inseridos no ambiente político fomentam ações de controle e proteção de suas próprias propriedades. O problema da terra e da reforma agrária mantém-se firme pelo vigor de um projeto político estrutural de convergência com a política neoliberal. Assim, os Sem Terra continuam a tentar romper com essas estruturas de poder lutando pelo direito à terra. Neste contexto, surgem as primeiras ocupações que dão origem aos acampamentos que são o nosso objeto, eles são veículos de materialização de uma luta do passado, continuada no presente e encaminhada para o futuro.

\subsection{A Chegada: vivência em um acampamento do MST}

No segundo semestre de 2015, cheguei em um acampamento do MST com receios do que poderia encontrar, mas muito entusiasmado. Um local pequeno, sitiado por eucaliptos, com cerca de 28 núcleos familiares e relativamente distante do centro urbano da cidade de São Sebastião do Passé, na Bahia. Eu era o adventício no local, profissional em formação, é verdade, mas logo na minha chegada percebi que os moradores já estavam acostumados com a visita de outros estranhos dado entusiasmo confessionário "olha, mais um da faculdade", euforia de alguns: “bem-vindo, novo amigo!” e olhares clínicos de outros.

Fui acomodado em uma casa de pau a pique (as acomodações foram previamente decididas pelo Núcleo de Estudos e Práticas em Políticas Agrárias - NEPPA ${ }^{3}$ ) que pertencia a uma senhora de meia idade que já estava presente na comitiva de boas-vindas. Enquanto caminhava pelo acampamento, envergonhado, mas risonho, disposto a ter os primeiros julgamentos positivos, percebi que as pessoas pareciam me olhar com curiosidade, me medindo, esquadrinhando-me em busca detalhes. Todos do acampamento dispunham de um gama de informações a meu respeito, sabiam da minha intenção na localidade e pareciam exultantes com minha chegada.

\footnotetext{
${ }^{3}$ O NEPPA é uma organização política de assessoria popular a movimentos sociais que vem atuando desde de 2006 na Bahia. Anualmente realiza o Estágio Interdisciplinar de Vivência e Intervenção em áreas de reforma agrária e em comunidades rurais, envolvendo estudantes universitários, profissionais e trabalhadoras e trabalhadores rurais e da cidade, é neste contexto que estou inserido.
} 
Passado alguns dias as pessoas continuavam com seus afazeres carregando madeiras, conversando nas portas das casas, reunindo-se na frente da associação e estendendo suas roupas nos arames farpados, enquanto eu seguia minhas andanças silenciosas pelo acampamento. Durante uma dessas andanças, um morador me convidou para participar de um café na casa de uma das primeiras moradoras do local, e de pronto aceitei. No decorrer de uma conversa acabei descobrindo que o acampamento surgiu em 18 de janeiro de 2003 e o processo de ocupação foi feito de modo remansado. Os trabalhadores da fazenda de eucalipto começaram a participar de reuniões do MST e resolveram fazer a ocupação de faixa de terra não utilizada pelo "patrão". O fazendeiro, com medo de perder a força de trabalho, acabou fazendo poucos enfrentamentos para retomada das terras.

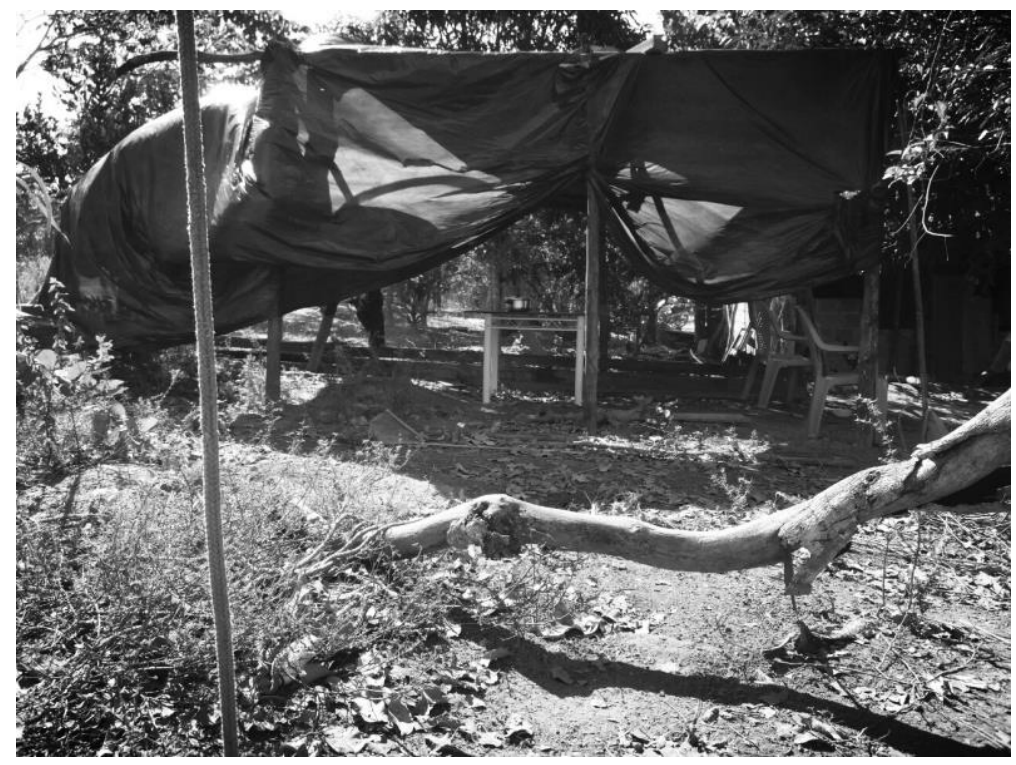

Fotografia 1 - Local de confluências

Fonte: Elaborada pelo autor.

Na oportunidade, a comida servida também despertou a minha atenção: charque, feijão e farinha de mandioca. Uma das moradoras acabou informando que "geralmente são feitas duas refeições diárias, por isso o café é mais reforçado para evitar fome durante o dia de trabalho, você vai se acostumar!". Em meio a comilança algumas pessoas começam rememorar como chegaram ao acampamento. Histórias de violências, abusos e exploração são compartilhadas. De alguma forma parecia que a minha escuta acabara quebrantando uma das primeiras fronteiras metafísicas e, embora não fosse um deles, parecia ser mais íntimo por ter ouvido um pouco sobre a vida privada deles. Todo aspecto relacional acabou mudando de um dia para o outro, na maioria dos casos passei a ser tratado de forma mais afetuosa - de modo bem-educado, confortável e mais amistoso. 
Com o tempo ganhei algumas atribuições na casa a qual estava alocado. Desse modo, lembrei que eu não era um hóspede, mas um pesquisador engajado sedento por maiores conhecimentos. Acabei sendo encarregado pela alimentação diária das galinhas e passei acompanhar a senhora que me acolhia em reuniões pontuais com os líderes do acampamento. Oportunidade única para saber mais detalhes sobre o rito de ocupação que tem momentos importantes como a própria chegada ao local, a formação de brigadas emergências pontuais, a criação posteriori de núcleos de bases responsáveis pela formação política, produção, discussão sobre gênero, educação, saúde, juventude, cultura, comunicação e à frente de massa encarregada pela alimentação do grupo. Com a consolidação desses núcleos é eleita uma representação fixa que atuará por dois anos intermediando demandas de seu grupo com os outros. Finalizando esse processo são escolhidos em assembleia geral dois coordenadores de área (sempre um representante do sexo masculino e feminino) que passam a ser responsáveis pela condução das demandas da associação, estreitamento das relações com o estado e o acompanhamento do processo de regularização de propriedade da terra. Como resultado disso, os laços sociais acabam sendo fortalecidos entre os partícipes que agora imersos em uma divisão social do trabalho assumem atribuições de forma ativa e compartilham o desejo da propriedade da terra ocupada.

Dias após minha chegada foi organizada uma festa junina comunitária. Ela acontece em dois espaços distintos e diametralmente opostos conhecidos na localidade como "rua dos loucos" e "rua dos crentes". Na primeira rua moravam, segundo minha interlocutora, "mulheres desquitadas", "lésbicas" e "homens embriagados" que haviam se aproximado durante o processo de consolidação estrutural do acampamento. Na outra rua moravam famílias que "chegaram prontas ou que se juntaram durante o processo" e em sua maioria professavam a fé cristã. Essas ruas eram dissemelhantes até mesmo em sua organização estrutural: na "rua dos loucos" as casas foram construídas muito próximas uma das outras "para facilitar a interação social" entre os residentes, já na "rua dos crentes" as casas tinham distâncias consideráveis pois "não precisavam de amparo uns dos outros". As festas também me pareceram diferenciadas. Na primeira, notei que havia um caráter mais de encontro de amigos onde quatro homens e uma mulher estavam sentados ao redor de uma mesa repleta de bebidas alcoólicas e uma pequena bacia de amendoim passada de mão em mão. Eles gargalhavam excessivamente e compartilhavam histórias da vida privada sobre flertes,

\footnotetext{
${ }^{4}$ Mulheres que separaram-se do marido, no entanto, sem intervenção judicial.
} 
traições e coisas afins. A minha chegada em nada parecia ter alterado o ambiente pois continuavam conversando, gargalhando, enquanto o estranho seguia despercebido. A minha presença era uma não-presença. Resolvi então seguir para outra festa. Logo quando cheguei nas proximidades as pessoas se movimentaram de todos os lados para me comprimentar, crianças me tocavam. De alguma forma, me senti mais agregado, mais humano. Foi-me oferecido um prato com algumas iguarias. Os moradores estavam reunidos em espécie de roda de conversa em que homens e mulheres pareciam estar bastantes atentos às histórias proferidas pelos "mais velhos" . Eles narravam histórias sobre a chegada na localidade, forma como se conheceram e entraram no movimento dos trabalhadores sem terra, quando fomos interrompidos pelo estopim do evento: o acendimento da fogueira comunitária. Empolgados com a efervescência do momento alguns continuam sentados "proseando"6 e outros se levantam para dançar forró.

O momento é interrompido por conjunto de gritos advindos da "rua dos loucos". Por uma recomendação da senhora que me alojava "filho, fique aqui não vá!” resolvi permanecer no local, mas fico sabendo por terceiros que havia ocorrido uma briga pela tutela de uma criança durante a festa entre pais "recém-desquitados". Alguns "mais velhos" notando minha preocupação, sentaram-se mais adjuntos e começam a dar continuidade ao processo de rememoração, agora, da construção do acampamento: “quando eu cheguei aqui só tinha umas 15 pessoas, eu já morava aqui! Sou filha daqui, aqui nasci e estou aqui até hoje. Não tem lugar melhor que aqui, um lugar sossegado que não tem violência. É mesmo que estar no céu sem problemas.", isso tudo acabou soando como uma tentativa de desmemoriamento do fato recém-ocorrido. Aproveitando o ensejo um dos "mais velhos" passa a realizar a defesa do movimento:

Uma coisa que tem que ser esclarecida. Antes da fazenda ser ocupada o movimento busca saber a situação dela junto ao Instituto de Colonização e Reforma Agrária - INCRA. Nós do movimento não saímos por aí ocupando aleatoriamente, a gente ocupa fazendas que tem problema de produção, um latifúndio. Aí a gente sabe que aquela fazenda pode ser disponibilizada para reforma agrária.( Interlocutora em Acampamento MST, São Sebastião do Passé.)

\footnotetext{
${ }^{5}$ Forma como eles se referem a pessoas idosas e com sabedoria resultante de sua experiência de vida.

${ }^{6}$ Forma como eles se referem ao ato de conversar sem compromisso.
} 
O MST realiza ações diretas de manifestação e ocupação como uma tentativa de correção à distorção da estrutura fundiária apontada no Relatório da Rede Social de Justiça e Direitos Humanos $(2003)^{7}$, na qual menos de 50 mil proprietários rurais possuem áreas superiores a mil hectares, controlam $50 \%$ das terras cadastradas e cerca de $1 \%$ dos proprietários rurais detêm em torno de $46 \%$ de todas as terras . O Estado observando essa questão acabou criando uma autarquia federal, em 1970, cuja missão prioritária é executar a reforma agrária cabendo a ela, também, a produção de parâmetros, índices e indicadores para determinar se a propriedade é produtiva ou não. O movimento utiliza-se dos resultados vinculados a improdutividade de algumas faixas de terra para ocupá-las, como relata um dos interlocutores:

O processo preparatório é verificar a situação da fazenda. Vê se ela tem pendência. Mesmo que a gente veja que está irregular frente ao INCRA, o que já nos permite fazer o trabalho de reforma agrária, sabemos ainda que estamos sujeitos de tomar uma ordem de despejo em função da reação do latifundiário. Inicialmente verifica-se o local, estrutura, organizamos a ocupação, ou seja, juntamos companheiros de dentro que fazem parte daquela ocupação e os novos que vão chegar. Reunimos essa gente toda, corremos atrás de alimentação para esse povo durante os primeiros dias e quantos dias for necessário ficar, buscamos estrutura de transporte, estrutura de lona para montar os barracos. A ocupação envolve setores que organizam os princípio do acampamento. No momento que se entra na fazenda já tem que ter isso tudo pensado e para ser colocado em prática o mais rápido possível. Organizamos as pessoas desde o primeiro dia com divisão de tarefas, áreas para saber onde serão montados os barracos. (Interlocutor em Acampamento do MST, São Sebastião do Passé)

Ao contrário do que muitos pensam, o processo de ocupação para reforma agrária é realizado dentro das leis vigentes, respeitando a propriedade privada e os direitos constitutivos. $\mathrm{O}$ órgão federal analisa se as terras que foram ocupadas são ou não produtivas. Caso sejam consideradas improdutivas os Sem Terra podem ser assentados na localidade recebendo a posse das terras, caso a propriedade seja considerada produtiva é expedida ordem judicial para reintegração de posse que, na maioria das vezes, ocorre sem maiores problemas. É necessário também destacar o processo de passagem do status de acampamento para assentamento. O acampamento é formado quando um grupo de pessoas sem terra se reúnem e ocupam uma dada terra, armam suas barracas de lona e resistem na localidade em condições

\footnotetext{
7 O inteiro teor do Relatório da Rede Social de Justiça e Direitos Humanos pode ser consultado em: https://www.social.org.br/relatorio2003/relatorio004.htm
} 
subumanas. Caso não recebam uma ordem de reintegração começam a estabelecer negociações com o governo para que o local seja destinado à reforma agrária. Assim, o acampamento torna-se um pré-assentamento, que é quando a comunidade está em aguardo da finalização de alguns processos burocráticos como o cálculo da área e a divisão dos lotes entre as famílias, condição primaz para torna-se assentamento. Um vez assentados os moradores passam a ter o direito para usufruto da terra e podem requerer alguns subsídios governamentais para consolidação de suas casas com alvenaria e para produção agrícola tendo enquanto obrigação continuar produzindo para gestar sua subsistência e renda.

\subsection{O Manejo coletivo: os casos da horta e do galinheiro comunitário}

A construção da horta comunitária partiu de um grupo de moradores que resolveram plantar seus alimentos na localidade para evitar o dispendioso deslocamento até o centro urbano. Uma das camponesas destaca que "antigamente tudo era mataria densa", mas com o tempo "demos outra forma" e o espaço tornou-se vital para comunidade. Há entre eles um processo de trocas de alimentos para supressão de necessidades ou pela realização de algum tipo de ajuda que é "paga" por um valor não comercial. Além de fomentar autonomia à vida dos camponeses, mais recentemente os alimentos produzidos acabaram gerando renda com a comercialização em feiras agroecológicas promovidas por algumas universidades baianas.

O delineamento do projeto da horta contou com reuniões periódicas em que foram discutidas as necessidades de cada núcleo familiar criando alguns ordenamentos para os beneficiários. Eles se dividiram em grupos de 6 pessoas que a cada semana ficam responsáveis pela manutenção do espaço, colheita e venda nas feiras. Caso não realizem sua função semanal devem depositar no fundo comunitário o valor de $\mathrm{R} \$ 30,00$ que é utilizado na compra de adubo e de outros materiais para a produção. $\mathrm{O}$ valor obtido pela venda é dividido coletivamente. Projetos como esses impulsionam o processo de desenvolvimento da agricultura familiar brasileira e dialogam com a necessidade de promoção do desenvolvimento sustentável gerando renda e desenrolamento local. Temos que reconhecer o potencial desse trabalho e apoiá-lo. No Brasil, projetos como esses acabam impulsionando o Produto Interno Bruto (PIB), que tem 10\% do total relacionado a agricultura familiar (MDA, 2014).

Segui para uma área no centro do acampamento um local repleto de brenha onde seria construído o galinheiro comunitário. Os galos e as galinhas geralmente são mantidos pelos moradores em pequenos cercados em suas casas, a construção desse espaço serviria para que a 
comunidade pudesse produzir mais ovos para consumo interno e venda externa. Eles haviam decidido que cada família deveria fazer uma contribuição simbólica para comprar materiais para estruturação do cercado, ajudar na montagem e doar "duas galinhas e um galo ou três galinhas". Assim, o criadouro comunitário foi aos poucos sendo erguido. As galinhas do espaço passaram a ser alimentadas diariamente com mistura de milho, cascas de vegetais, farelos de soja e trigo para que continuassem pondo ovos diariamente, segundo um senhorio,"essa mistura ajuda no ciclo hormonal delas e por consequência gera a produção diária de muitos ovos". Em suma, o trabalho em grupo ou coletivamente não é uma tarefa fácil, afinal ele não faz parte da cultura de uma grande maioria, tampouco da nossa realidade política-social; vivemos em uma sociedade individualista, somos forçados a competir muitas vezes por espaços, ganhos e afins. Acabo encontrando nesse acampamento um exemplo da própria contradição da sociedade, onde habitantes de uma mesma comunidade trabalham em equipe para enfrentar desafios e mudanças das condições de vida consolidando projetos que visam o desenvolvimento individual e grupal.

\subsection{A Partida: aprendizagem baseada em problemáticas}

Combinando a presença, intensificação dos diálogos e intimidade, passei a buscar mais informações sobre o processo de ocupação daquela terra e a tentar responder algumas questões como: quantas famílias estavam aqui durante o processo de ocupação? Por que restaram apenas cerca de 28 famílias? Por que aquele local ainda é considerado um acampamento e não um pré-assentamento? Essa operação parecia inicialmente muito delicada pois traria cicatrizes de um passado não tão distante. A sapiência parecia me conduzir novamente, um senhorio me informa que seria realizada uma ciranda infantojuvenil no acampamento, que é uma atividade formativa através de brincadeira, jogos para crianças e adolescentes sem terra. Com a finalização da ciranda as crianças e adolescentes são levados para suas casas e grande maioria dos pais seguem para a sede da associação onde aconteceria uma reunião para debater questões internas e emitir alguns encaminhamentos.

A reunião tem início com a realização de uma mística. A bandeira do movimento é estendida sobre o chão e em meio ao silêncio começa-se a entoar o hino do MST. Desde o seu surgimento o movimento vem criando diversos símbolos para representar sua luta. A bandeira e hino são, sobretudo, signos da unidade do movimento, segundo uma consorte, esses elementos dizem muito do movimento " a bandeira vermelha simboliza o sangue de 
muitos companheiros e companheiras que são derramados anualmente na luta por um pedaço de terra e o hino é a síntese do orgulho de ser quem sou, quem somos". Com a finalização deste ato e o grito de algumas palavras de ordem os coordenadores locais passam a conduzir a reunião. Inicialmente eles fazem um breve relato histórico sobre a ocupação:

Quando chegamos nesse lugar ele estava ocupado por inúmeras barracas. 300 famílias ocupavam, brigas e atritos eram constantes. A lei era feita por meio do consenso, não existia tempo para invocar uma forma democrática como hoje. O INCRA veio e cadastrou as famílias, muitos deles foram feitos em 2006 e um dos critérios era ver se as nossas mãos tinham calos ou não. Esse era o critério para delimitar quem era ou não sem terra. Com o cadastramento restaram apenas 100 famílias. O movimento veio e levou muitos destes para outras ocupações. Começamos o trabalho de base e o êxodo continuou ocorrendo, e o movimento definiu que apenas 28 famílias ficariam (Interlocutor em Acampamento MST, São Sebastião do Passé).

Com essa fala consigo ter acesso a outros processo ocultos. A disputa interna no início da ocupação e posteriormente pelo reconhecimento enquanto sem terra, realizado pela autarquia federal utilizando, segundo o relato, critérios físicos como "ter ou não calos nas mãos". Depois observa-se um estímulo externo do próprio movimento para saída de algumas famílias que são conduzidas para outras ocupações. O trabalho de base é um dos elementos definidores para permanência no local conjugado com critérios subjetivos e objetivos como a adequação na área e o tamanho do local para definir o quantitativo final de famílias que continuarão a ocupar o espaço. Esses momentos são de extrema relevância para entendimento das minúcias e questões complexas envoltas do processo de ocupação e permanência, eles não estão escritos, apenas descritos.

A palavra é concedida para os partícipes da reunião e acabo ouvindo séries de narrativas convergentes. Em meio a um silêncio que grita, resolvi consultá-los para saber as razões que impedem a localidade de ser considerada um assentamento. Algumas respostas me chamaram atenção "não existe um consenso para regularização fundiária", "a divisão proposta é deficitária", "nem tudo se tem resposta ou precisa ser dito". Mediante ao exposto vejo que além dos conflitos de ordem burocráticas algumas disputas pelo poder interno tornam a situação ainda mais dispendiosa. Anteriormente eram 28 núcleos familiares, hoje novas famílias foram formadas e as tarefas de terras que se tem não são passíveis de reforma agrária por não contemplar integralmente o quantitativo de habitantes, sendo necessário a ampliação do espaço. Em meio a essa roldão a comunidade começa a resgatar o ocorrido na festa junina e através de votação aberta decidem que o causador da briga permanecerá na comunidade. Ao final da reunião, sou interpelado por uma morada com a seguinte questão: “ Me responda por 
que essa terra tem dono? Por que uma fazenda desse tamanho era só de um dono e hoje comporta mais de 28 famílias?" As respostas ficaram ocultas naquele momento, mas hoje percebo mais do que nunca a importância desse movimento que por meio de ação direta ocupa terras improdutivas gerando a sobrevivência de inúmeras pessoas que são mobilizadas através de atos democráticos e que pressionam as autoridades para que a lei seja aplicada a seu favor, já que no nosso país as leis só são aplicadas para os donos do poder.

\section{Vivência cultural em comunidade quilombola e em uma comunidade pesqueira}

Visitei, em 11 de outubro de 2016, duas comunidades: uma quilombola e outra de pescadores na localidade de São Francisco do Paraguaçu, no município de Santo Amaro da Purificação, na Bahia. A área onde essas comunidades estão fincadas está em meandros do rio Paraguaçu. Existem dois modos de acessá-las, o primeiro deles por estradas secundárias da BR-324 e o segundo seguindo o flúmen do rio. Inicialmente, naquelas proximidades desenvolveu-se, em 1660, um vilarejo que deu origem a cidade de Santo Amaro, mas com a expansão interiorana outros espaços foram invadidos para construção de engenhos o que forçou o deslocamento coercivo de um grande contingente de pessoas escravizadas para localidade. Esse momento aparece enquanto oportunidade de fuga para os cativos que em meio às matas ainda inexploradas formaram seus primeiros espaços de resistências dando origem ao que conhecemos hoje como Quilombo de São Francisco de Acupe e a Comunidade de pescadores de Porto de Acupe.

\subsection{Quilombo de São Francisco de Paraguaçu}

A partir da massiva debandada, os escravos fugidos se estabeleceram e passaram a construir os primeiros quilombos na localidade como, por exemplo, o Quilombo do São Francisco de Paraguaçu também conhecido como Boqueirão, local de partida da vivência. 


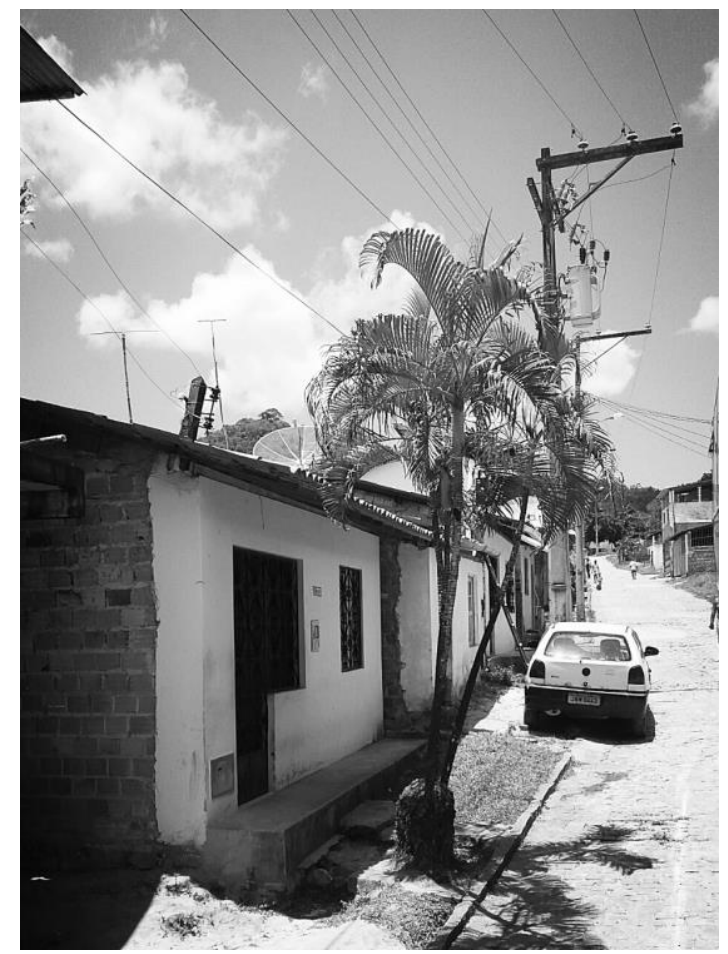

Fotografia 2 - Rua do Boqueirão

Fonte: Elaborada pelo autor.

Ao chegar neste local, fui recepcionado pela então representante quilombola Zeferina Luz $^{8}, 18$ anos, que logo indagou-me sobre as motivações da minha visita ${ }^{9}$. Me identifiquei e informei que iria realizar um trabalho de observação de campo em algumas comunidades do Paraguaçu. A então representante se propôs a me fornecer sua companhia, de bom grado aceitei. Adentrei uma rua paralelepipédica com a interlocutora, caminhamos cerca de 200 metros até que comecei a avistar as primeiras habitações. Trata-se de uma área com significativa cobertura vegetal e grande quantidade de árvores frutíferas.

Defronte de algumas habitações papéis com os dizeres "Não sou quilombola", "Sou quilombola" chamam a minha atenção. Segundo Zeferina, aquela comunidade foi edificada por remanescentes das fazendas de engenho. Com o passar do tempo alguns habitantes de outras regiões passaram a fixar moradias no território, o que não era encarado como um problema inicialmente pois em sua maioria apenas migravam a veraneio, mas a partir do momento no qual a comunidade começou a se mobilizar por sua legitimação frente aos

\footnotetext{
${ }^{8}$ Por opção do pesquisador o verdadeiros nomes dos interlocutores foram preservados e substituídos por nomes de heróis e heroínas negros (as) que marcaram a história do nosso país.

9 Visita agendada para produção de relatório antropológico para disciplina de Etnografia do curso de Ciências Sociais da Universidade do Estado da Bahia - UNEB.
} 
poderes públicos enquanto quilombola houve os primeiros embates entre eles:

O lugar aqui, nós sempre fomos donos e convivíamos bem com outros moradores que vêm veranear. A comunidade começou a sofrer perseguição e brigas quando nós quilombolas começamos a lutar para sermos chamados de quilombolas. Os fazendeiros das áreas próximas começaram a dizer que nós não éramos quilombolas, os moradores a veraneio também. Nesta época, a Rede Globo também fez matérias contra nós, discriminando nossa gente e dizendo que a gente destruía e não era quilombola. Até na escola a professora proibia que a gente chamasse nossa gente de quilombola (Interlocutora em Quilombo de São Francisco do Paraguaçu, Santo Amaro).

Em 2007, a Comunidade do Boqueirão começou a empreender um de seus enfrentamentos mais corpulentos. Os fazendeiros da localidade agora unidos aos proprietários das casas de veraneio, que viam na titulação do território enquanto quilombola uma ameaça direta a suas propriedades, iniciaram um conjunto de combates ideológicos, armado na localidade. Como se não bastasse, a emissora de televisão brasileira Rede Globo, em 14 de maio de 2007, vinculou em seu telejornal de maior audiência noturna, o Jornal Nacional, uma reportagem contra a comunidade sob o título "Suspeitas de fraude em área que vai ser reconhecida como quilombo" ${ }^{10}$ com informações inverídicas e tendenciosas sobre os moradores e a comunidade. A Fundação Cultural Palmares responsável pela elaboração da certidão de autorreconhecimento das comunidades quilombolas brasileiras, mediante o exposto, instaurou sindicância para apurar as denúncias e considerou legítima a preposição dos comunitários dando continuidade ao procedimento administrativo para regularização da área remetendo-o ao INCRA para elaboração do Relatório Técnico de Identificação e Delimitação - RTID. Um novo mandado de reintegração de posse é deferido em favor dos fazendeiros, neste novo momento máquinas adentram a comunidade e destroem o principal local usado para reuniões, decisões, conversas dos comunitários, a sede da Associação dos Remanescentes do Quilombo de São Francisco do Paraguaçu Boqueirão.

Fui conduzido ao local mais emblemático das repressões e violências as quais vêm sendo submetida essa comunidade por legitimação da força estatal, trata-se da sede que foi novamente reconstruída pelos moradores que até a finalização dessa descrição ainda aguardavam o findar do processo de reconhecimento. Retornando para o carro que me conduziria a outra localidade pude observar conjunto de frases em outras residências: "nós

\footnotetext{
${ }^{10}$ Matéria pode ser conferida na integra em: https://www.youtube.com/watch?v=_vEcbpMQeAU
} 
somos quilombolas com muito orgulho", "sei o que é por isso somos quilombolas" uma demonstração explícita ao autorreconhecimento e a permanência de uma luta incansável pela causa quilombola.

\title{
3.2. Comunidade de Porto de Acupe
}

Logo ao desembarcar na comunidade tradicional de Porto de Acupe, avistei uma pequena vila que se entendia por um viel defronte a um manguezal. Homens concentram-se à beira do rio e na proximidade de um casebre. Eles tinham acabado de chegar de mais um período de pesca. Um deles, o senhor Francisco José de Nascimento, que aparentava os seus 54 anos, logo me antecipou: "aqui funciona a sede da comunidade, nos reunimos e guardamos os materiais de pesca aqui, dividimos funções.” Era interessante notar que enquanto relatava questões estruturais ligadas a sede ele dava continuidade a tecelagem de uma rede de pesca artesanal com ajuda de uma agulha rústica e linha de nylon.

Me despedi e segui para proximidade do rio onde embarcações coloridas estavam atracadas, pessoas jogavam jogos de azar e era possível avistar ao fundo um largo com inúmeras pessoas sentadas. Caminhei pelas margens do rio e acabei me deparando com uma grande representação de Iemanjá, um orixá africano do povo Edga (ABIMBOLA, W; MILLER, I. 2003) exposto de maneira imponente e na sua proximidade uma parede com um escrito me chamou atenção:

\author{
O Lanço La vem ele \\ Na cadência da remação \\ Formando um som \\ Submisso aos movimentos \\ Das mares \\ Trabalha na vazante \\ Descansa na enchente \\ Senhor doutor conhecedor \\ E respeitador do ventos \\ Cacad de mar \\ Homem valente \\ Cante Sta Cstador (s.a; s.d.)
}

O texto me remeteu diretamente ao primeiro contato imagético com a comunidade, onde homens chegavam de mais um dia de pesca. $\mathrm{Na}$ localidade preserva-se aspectos da pesca tradicional com uso da mão de obra familiar, uso de jangadas e canoas. Essa comunidade em específico era afamada pela venda de moluscos e peixes, mas que acabou 
sendo comprometida pelo cultivo de camarões feito por uma "empresa da terra"11. O acúmulo de toxinas liberadas por esses crustáceos quando criado em espaços limitados acabara destruindo parte do manguezal e comprometendo a renda dos moradores até os dias de hoje.

Segui pelas ruas do Porto de Acupe, depois de minutos de caminhada cheguei a uma das ruas mais conhecidas: a "rua do vai quem quer". Segundo uma das residentes, ela foi formada mediante o deslocamento de um grupo de negros e negras cativos que trabalhavam em um engenho no período colonial. A região possuía uma forte produção cacaueira, mas foi devastada pela "vassoura de bruxa" ${ }^{2}$, aproveitando esse momento de caos para seus senhores, os negros cativos empreenderam inúmeras revoltas. Os seus donatários com medo de maiores conflitos passaram a fazer algumas concessões dentre elas a permissão para consolidação de moradias nas proximidades do engenho, mas para manter o controle da localidade, os senhores também fixaram residência na vizinhança,a rua então ocupada ficou afamada como "rua do vai quem quer". É nessa rua que também podemos encontrar nas portas das casas cestos repletos de peixes estendidos ao sol. O peixe na ocasião é o xangó comercializado em sacos plásticos de $500 \mathrm{ml}$ preenchido, como afirma a vendedora, através de "dez mãozadas" ao preço de $\mathrm{R} \$$ 5,00 (cada saco), grande parte daquela produção artesanal é comercializada para a cidades vizinhas,

Resolvo fazer aquisição de algumas socas da especiaria e a então vendedora aproveita a oportunidade para fazer um convite: "você tem que vir aqui para participar da festa das caretas de Acupe”. Essa festa ocorre anualmente no mês de julho e lota as ruas da comunidade, segundo o escritor Deraldo Argôlo, esse evento teve início quando um proprietário de um engenho trouxe máscaras para sua festa privativa e os indivíduos escravizados tiveram a ideia de fabricar suas próprias máscaras para se inserirem na festa do ano seguinte e assim deu-se início a tradição (ARGOLO, 2016). As brincadeiras das caretas de Acupe são contribuição direta da cultura negra que ao inserir e se perpetuar em meio ao ambiente hostil do período colonial materializaram elementos de suas identidades nas máscaras. Com essa valorosa parada para compra de xangó e com esse precioso convite, me despedi da comunidade tradicional de Porto de Acupe. Embora esses relatos

\footnotetext{
${ }^{11}$ Forma como eles se referem a empresas locais.

${ }^{12} \mathrm{O}$ termo vassoura-de-bruxa é aplicado a um tipo de doença de plantas em que ocorre um desenvolvimento anormal do tecido meristemático sendo um problema fitopatológico no estado da Bahia.
} 
sejam de duas comunidades específicas e distintas a primeira vista, ambas estão unidas pelo desejo de reconhecimento, fortalecimento e garantia dos seus direitos ambientais, culturais, econômicos e sociais. $\mathrm{O}$ respeito e a valorização das identidades quilombolas e pesqueiras é obrigação-mor nossa e do Estado brasileiro. Assim, garantimos a sua sobrevivência, permanência e continuidade no espaço onde suas raízes ancestrais estão fincadas.

\section{A passagem por comunidades indígenas bolivianas e peruanas}

Imagine que, de repente você é selecionado para participar de uma expedição com vocação de universidade itinerante da sabedoria ancestral ${ }^{13}$ que, entre 19 de junho a 21 de agosto do ano de 2015, percorreria santuários, reservas naturais, conheceria povos nativos e comunidades tradicionais da Bolívia e do Peru. Imagine, também, já estar no avião voando em direção a esses países, cujos nomes apareciam pontualmente nas manchetes de jornais e na televisão devido aos encontros entre os nossos governantes ou por conta de sanções de acordos de cooperação econômica. Era essa minha situação em 18 de junho de 2015. Logo me veio a lembrança de Bronislaw Malinowski ${ }^{14}$, que diferente dessa situação adentrou em um novo continente sob condições melhores mesmo sem saber a língua nativa, mas com a real certeza de que encontraria um outro povo com uma cultura totalmente distinta da sua e um "informante” ao menos bilíngue para auxiliá-lo.

O cenário inicial da Bolívia visto através da janela do automóvel parecia um pouco comum, principalmente quando se é brasileiro. De certo ângulo, observei um grande assentamento, com moradias precárias de tijolos sem reboco, ocupando todo um enorme vale de alta altitude e com trânsito totalmente caótico, o que fazia lembrar alguns bairros suburbanos das nossas metrópoles com intensa vida social. Mulheres passavam, sobre o meu olhar, carregando grandes cestos nas cabeças e com filhos recém-nascidos levados nas costas envoltos em panos coloridos, crianças brincavam nas ruas sobre amontoados de entulhos e grupos de homens ocupavam as esquinas ao que parece proseando. Durante o trajeto observei alguns comportamentos intrigantes, as ruas não possuíam sinalização, por isso era comum observar pessoas disputando lugar nas avenidas com os carros, flagrei um pequeno número de homens e mulheres fazendo necessidades fisiológicas nas esquinas em meio à indiferença dos que passavam sem se incomodar ao menos com o meu olhar excessivo, por diversas vezes ouvi comentários dos passantes em uma língua

\footnotetext{
13 Participei da Expedição Ruta Inka organizada pela Embajada Cultural de Pueblos Milenarios, em 2015. .

${ }^{14}$ MALINOWSKI, B.Argonautas do Pacífico Ocidental. São Paulo: Abril Cultural, 1978.
} 
desconhecida, só sabia que eram direcionados a mim pelo uso constante da palavra "gringo". Assim, os primeiros sinais morais e sociais começavam a se estruturar no meu diário.

\subsection{Copacabana}

Desembarquei na praça central de Copacabana, localizada a 3.841 metros acima do nível do mar e a 115 quilômetros da cidade de La Paz. O nome da cidade deriva da expressão kota kahuana do dialeto Aymara, que significa "vista do lago". Nesta cidade está localizada a Igreja de Nossa Senhora de Copacabana, padroeira da Bolívia, cuja réplica foi levada, no século XIX, por comerciantes espanhóis até a cidade Rio de Janeiro, no Brasil, onde angariou fiéis e passou a denominar uma das praias mais afamadas do mundo. Essa cidade é considerada um dos portais para chegar ao lago Titicaca. No momento da chegada fui encaminhado para um sítio arqueológico no qual passaria a noite para acompanhar o início do novo ano inca de 5523. As 4 h da manhã fui despertado para fazer a subida da montanha sagrada com um grupo de licenciados que foram me explicando durante o caminho a importância daquele momento para comunidade interna e externa, pois sinalizaria se o novo ano seria boas colheitas ou não. Chegando ao topo, observei grupos com diferentes indumentárias dançando ao som de instrumentos de sopro e logo fui alertado por um dos licenciados: "Aquí en lo alto todos son iguales, las diferencias se olvidan" $" 15$. O sacerdote nos convida a receber energias positivas mediante a condução das palmas das mãos em direção ao sol, o grande momento se aproxima e temos que nos dirigir ao pico da montanha para acompanhar a entrada dos raios solares. Aos poucos os raios vão iluminando o lugar, pedra por pedra, até que penetram em uma pequena fenda no estopim das 8 horas. Se a extremidade da direita fosse iluminada primeiro, o ano seria de boas colheitas, caso o lado esquerdo fosse primaz, o ano seria de grandes dificuldades. Neste ano, os raios solares acabaram por iluminar o lado esquerdo, mas, segundo palavras do sacerdote, durante todo o ano serão feitas oferendas para que não se repetisse o alagamento que quase fez sumir a cidade em uma época passada. Com o fim dessa experiência segui à risca o que diziam o sacerdote local: “Copacabana es sólo un lugar de paso un portal para desbravar el Titicaca"16 , assim dei continuidade a viagem em direção a antigos domínios do Império Inca.

\footnotetext{
15 Tradução: Aqui no topo somos todos iguais, as diferenças são esquecidas.

${ }^{16}$ Tradução: Copacabana es só um lugar de passagem para os antigos domínios do império inca.
} 


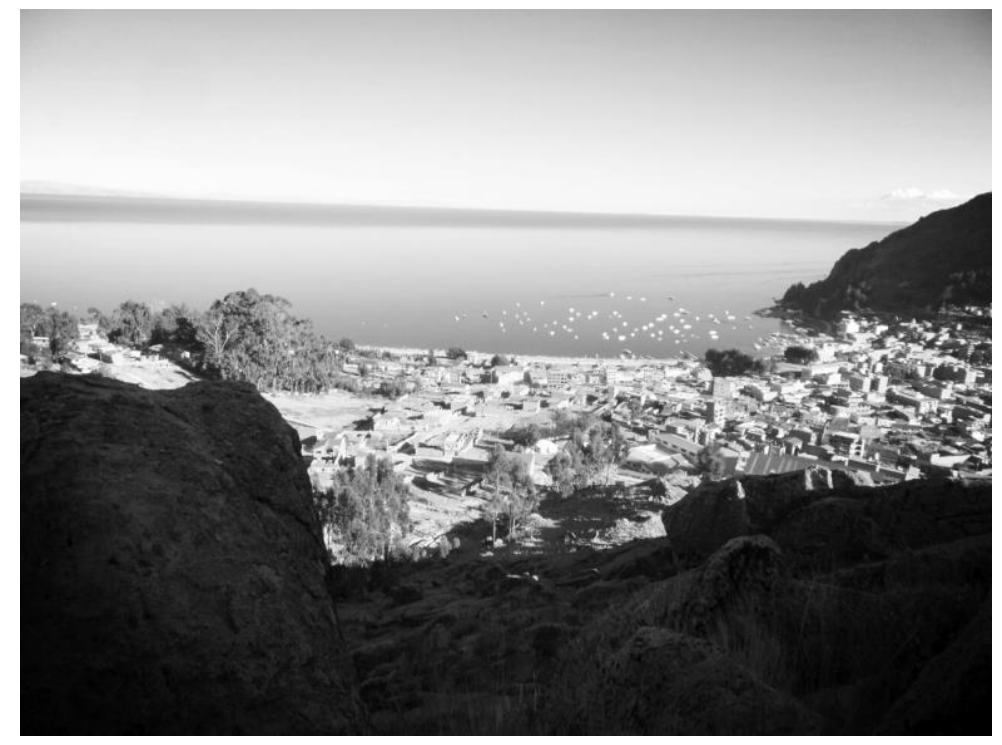

Fotografia 4 - Alto de Copacaba

Fonte: Elaborada pelo autor.

Durante a viagem pelo lago passei a conhecer um pouco mais da cosmologia e da mitologia dos incas, por meio de relatos orais do barqueiro, ele detalhou o processo de criação do mundo, o surgimento dos astros e o aparecimento das plantas, animais e seres humanos. Uma das histórias mitológicas mais intrigantes versava sobre o surgimento do sol e da lua:

Viracocha, el creador supremo, creó los seres humanos desde la tierra y los colocó en cuevas, ellos por medio del deseo salieron y fueron a poblar el mundo exterior. El creador resuelve entonces enviar a sus dos hijos Mama-Quilla y Manco Cápac para vivir en ese mundo, respectivamente en las islas de la Luna y del Sol, en el lago Titicaca, pero ambos hallaron el mundo caótico y desprovisto de luz. Con el tiempo se casaron de aquel lugar y en la búsqueda de lugar para el establecimiento de sus reinos, se erigieron de las islas y siguieron en dirección noroeste y pasaron a asumir una nueva persona Mama se convirtió en la luna y el sol el Sol.(Interlocutor em Copacabana, Bolívia) ${ }^{17}$

Os pontos onde eles emergiram passaram a integrar a rota mundial do turismo místico e esotérico, que se caracteriza por ter um público que busca o aprofundamento de

\footnotetext{
${ }^{17}$ Tradução: Viracocha, o criador supremo, criou os seres humanos a partir da terra e os colocou em cavernas, eles por meio do desejo saíram e foram povoar o mundo exterior. O criador resolve então enviar seus dois filhos Mama-Quilla e Manco Cápac para morar nesse mundo, respectivamente nas ilhas do Lua e do Sol, no lago Titicaca, mas ambos acharam o mundo caótico e desprovido de luz. Com o tempo eles casaram-se daquele local e na busca de lugar para o estabelecimento dos seus reinos, ergueram-se das ilhas e seguiram em direção noroeste e passaram a assumir uma nova persona Mama tornou-se a lua e Manco o sol.
} 
sua espiritualidade e o autoconhecimento por meio de práticas, crenças e rituais. Nesse contexto, fui privilegiado, pois não estava apenas de passagem pela aquela localidade, ali iniciei a minha primeira vivência in loco em uma pequena ilha vizinha com uma família constituída pelo jovem barqueiro e sua mãe de idade avançada que não sabia falar espanhol, mas que por meio de gesticulações se fazia entender rapidamente. Esse momento foi de suma importância para mim, pois além de ser o primeiro contato direto com uma família de nativos houve profundas trocas de conhecimento e saberes registrados em meu diário e em minha memória.

\subsection{Puno}

Regressei às águas do lago para seguir para ilha Amantani, uma joia imersa no Titicaca, conhecida por ser uma das ilhas de maior altitude no mundo. Ainda no horizonte, com ondas se abrindo ao meu favor, era possível ver uma ilha com alguns casebres até o seu pico, ao me aproximar observei que moradores já me esperavam acenando com lenços de múltiplas colorações. Descendo da embarcação, crianças se aproximaram para me entregar colares de flores e acabei sendo conduzido a praça central, repleta de gente em volta de um tablado. Já ocupando o espaço a que me foi destinado, sou apresentado a população, que com gritos e palmas esboçam reações distintas pela minha chegada. Crianças e adolescentes fazem algumas exibições performáticas.

Prossegui para um grande banquete oferecido pela municipalidade e líderes comunitários. Conduzido a um espaço vazio e de chão forrado com panos tradicionais observo a entrada de mulheres, que desarmaram os lenços das costas e acrescentam suas contribuições alimentícias ao chão para comezana. Elas vão aos poucos compondo um grande círculo, os homens que chegam a posteriori trazem cadeiras e sentam nas imediações das mulheres. Começam as primeiras partilhas no anel humano, as mulheres servem primeiro aos homens e logo depois também se servem. Após observar a configuração deste cenário, inicia-se a comilança, a disposição muitas espécies de batatas e empanadas peruanas. Encerrado esse momento, regressei a embarcação e segui para uma das ilhas de Uros. Essas ilhas artificiais possuem existência desde a era pré-colombiana, foram construídas inicialmente por um povo homónimo que, com medo dos inimigos vindos por meio terrestres, passaram a construí-las com totoras no meio do lago Titicaca. Hoje, cerca de 84 famílias de origem peruana e boliviana ali residem, sobrevivendo da pesca, caça de pássaros e da venda de artesanatos para os turistas que visitam as ilhotas. Por ali me alojei e, antes cair do sol, rememorei alguns momentos únicos que aqueles 
nativos estavam me proporcionado com o compartilhamento desse saber local, que relativiza a impossibilidade de ser um deles ou penetrar sob suas peles, e por isso segui na tarefa difícil de tentar "traduzir" aquela realidade posta.

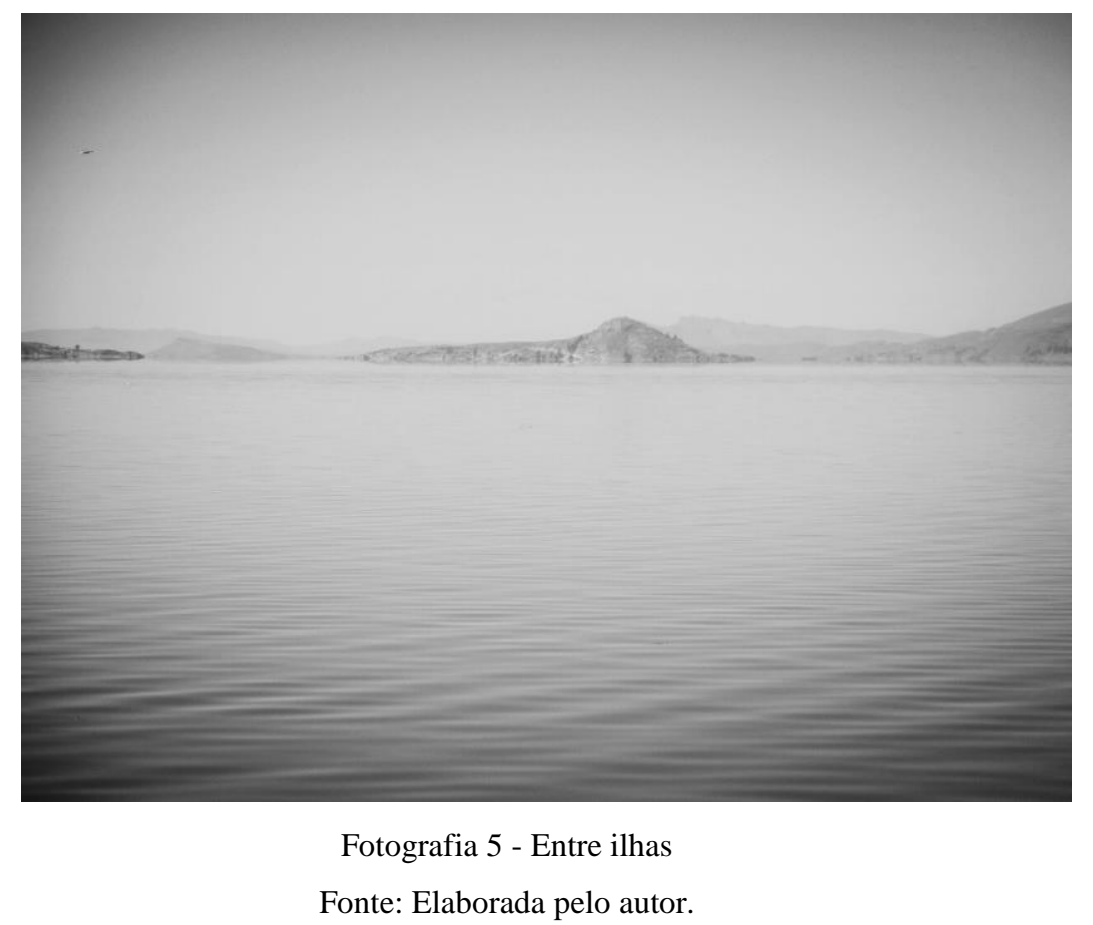

Por meio da elaboração do diário de campo me percebi exercendo o principal ofício do etnógrafo, seguindo à risca as diretrizes dos manuais clássicos e contemporâneos da "disciplina etnografia". Esse instrumento foi imprescindível como recurso metodológico, nele registrei aspectos importantes sobre aquelas populações. Fui tentando, também, relacionar os eventos observados ou compartilhados de comunidade a comunidade, abusando das descrições densas, sem nenhuma omissão, como pede essa "técnica que tem por base o exercício da observação direta" (WEBER, 2009, p.157), acumulando um grandioso material que irá servir para novas análises das práticas sociais, dos discursos e posições dos envolvidos, que assessorado por movimentos de costura teórica realizando uma das possíveis narrativas e interpretações dos nativos dirigidas ao grande público e em diálogo com o campo científico dos estudos da culturais.

\section{Conclusões}

Apesar do esforço de permanecer o mesmo, receio que não sou. $\mathrm{O}$ que me levou a destinos desconhecidos foi a possibilidade de experimentar uma nova cultura, conhecer novos 
hábitos, entrar nas casas daqueles sujeitos. Participar de cada ato da vida social seja nas ruas ou no cemitério resultaram na reunião de um conjunto de artefatos culturais, fotografias, impressões que me fizeram por essas experiências em perspectiva e como perspectiva.

Mas o que aprendi nesse processo como todo? As vivências contribuíram para minha formação técnica e social de forma mais comprometida. O processo como todo consegue extrapolar os limites do currículo universitário servindo como uma proposição de uma nova forma ou modelo educacional. Devo destacar, também, seu potencial transformador que é passível de alteração ao longo do processo dialógico. A minha representação sobre realidade daquelas comunidades aos poucos foi sendo modificada, e assim, minhas próprias ações sobre essas realidades. Passei a ser um pesquisador que literalmente colheu frutos no campo de pesquisa pronto para disseminar as semestes plantadas. A relação entre o pesquisador e os nativos, universidade e movimento social permitiu construir conhecimentos juntos, tecendo outras narrativas e construindo novas perspectivas. Ao final, fragmentei com ideia de objetificação daqueles corpos e mentes tornando-os sujeitos que modificam outros sujeitos e isso é uma dádiva.

A partir de minha vivência pessoal, registros fotográficos e diálogos com os nativos, tentei romper com a polarização existente entre o saber científico e o popular, através de uma interpretação friccional mediante a trocas de informações, compartilhamento de saberes e segredos suprimidos. O meu compromisso social e profissional perpassa toda essa produção, sendo possível destacar a minha mudança exterior e interior. Durante esse processo formativo, destaca-se, também a aproximação das comunidades e povos nativos que permitiram e gestaram possibilidades de (re) interpretá-los, tentando romper com a barreiras do espaço acadêmico sugadouro e determinista. Aprendi que aqueles sujeitos eram apenas outros sujeitos e não exóticos objetos. Consequentemente a vivência, presença e os diálogos garantiram a ampliação da visão dos movimentos sociais, comunidades e povos tradicionais do nosso continente. Em suma, acabei bebendo da taça do pensamento, raciocinei até achar a verdade, achei-a e ela já se esvai. Seguimos.

\section{Referências}

ABIMBOLA, W; MILLER, I. Ifá Will Mend Our Broken World: Thoughts on Yoruba Religion and Culture in Africa and the Diaspora. Iroko academic publishers, v.2, 2003.

ARGÔLO, D. Caretas de Acupe. 2016. Disponìvel em:<http://www.obomdoacupe.com/2011/ 
08/acupe-caretas-de-acupe.html>. Acesso em 12 de outubro de 2018.

BARBOUR, J.The end of time: the next revolution in our understanding of the universe. England: Oxford U, 1999.

BRASIL. Ministério do Desenvolvimento Agrário (MDA). 2013. Disponível em: <http://www.mda.gov.br/>. Acesso em: 20 de Dezembro de 2018.

GEERTZ, C. A interpretação das culturas. Rio de Janeiro : LTC, 2008.

RELATÓRIO DA REDE SOCIAL DE JUSTIÇA E DIREITOS HUMANOS. Rede Social de Justiça e Direitos Humanos, 2003. Disponível em: <https://www.social.org.br/index.php/relat orios/relatorios-portugues/50-direitos-humanos-no-brasil-2003.html>. Acesso em: $20 \mathrm{de}$ novembro de 2018.

WEBER, F. Trabalho fora do trabalho: uma etnografia das percepções. Rio de Janeiro: Geramont, 2009, p. 157. 